\title{
Bacteriological Examination of Utensils and Hands of Food Vendors in a University Cafeteria in Enugu, Nigeria
}

\author{
R. A. Afunwa (Corresponding author)
}

Department of Microbiology, Faculty of Natural and Applied Sciences, Godfrey Okoye University, Thinker's corner, Enugu state, Nigeria E-mail: missruthus2000@yahoo.com

$$
\text { G. O. Igwe }
$$

Department of Microbiology, College of Natural and Applied Sciences, Renaissance University Ugbawka, Enugu State, Nigeria

$$
\text { E. C. Afunwa }
$$

Department of Clinical Pharmacy, Faculty of Pharmaceutical Sciences, University of Nigeria, Nsukka, Enugu state, Nigeria

$$
\text { C. U Ezebialu, M. N. Unachukwu }
$$

Department of Microbiology, Faculty of Natural and Applied Sciences, Godfrey Okoye University, Thinker's corner, Enugu state, Nigeria

$$
\text { C. E. Okoli }
$$

Department of Microbiology, College of Natural and Applied Sciences, Gregory University Uturu, Abia State, Nigeria

Received: November 18, 2018 Accepted: December 28, 2018

doi:10.5296/jbls.v10i1.14267 URL: https://doi.org/10.5296/jbls.v10i1.14267

\begin{abstract}
The bacteriological quality of crockery, cutleries and hands of food sellers in a university cafeteria was determined. A total of one hundred and forty eight (148) samples were collected over a one month period and isolates were identified using morphological appearance on both selective and differential media and a series of biochemical test. The biochemical tests carried out were coagulase, indole, motility, catalase and oxidase. Antibiogram study was also carried out. The organisms identified were Staphylococcus aureus, Shigella spp., Salmonella spp, Escherichia coli and Klebsiella spp. The result of the sensitivity test showed $75 \%$ resistance to the conventional antibiotics used; namely,
\end{abstract}


ciprofloxacin, amoxicillin, gentamycin, ampicillin and erythromycin. The total bacterial counts $(\mathrm{cfu} / \mathrm{ml})$ of the samples were $2.6 \times 10^{7} \mathrm{cfu} / \mathrm{ml}$ for hand swab, $8.0 \times 10^{5} \mathrm{cfu} / \mathrm{ml}$ for plates, $1.08 \times 10^{6} \mathrm{cfu} / \mathrm{ml}$ for knives, $9.6 \times 10^{5} \mathrm{cfu} / \mathrm{ml}$ for pots, $9.2 \times 10^{5} \mathrm{cfu} / \mathrm{ml}$ for spoons and $1.62 \times$ $10^{6} \mathrm{cfu} / \mathrm{ml}$ for tables. The results suggest high levels of microbial contaminants and calls for improved personal and environmental hygiene.

Keywords: crockery, cutleries, sensitivity, antibiotics, bacterial count

\section{Introduction}

The cafeteria is a place where foods are prepared and sold. It is a means of livelihood for a significant number of people in developing countries but the poor hygiene conditions in some of these cafeterias raise worries on microbiological safety. Food borne infections in cafeterias can result from improper storage, contamination from raw foods and or from utensils carrying pathogens (Majlesi et al, 2014). Nigeria like most developing countries has occurrences of bacteria cross contamination in foods (Edema, et al, 2008; Okonke, et al, 2009). These prepared foods are sold at parks, schools, markets and other public places. They are also offered to the consumers at relatively cheaper rates and at easily accessible places hence the high patronage (Oranusi and Braide, 2012).

Food serves as an excellent substrate for microbial growth due to the rich nutrient content suitable for the proliferation of microorganisms. Microbial food spoilage can either occur as a consequence of the growth of microorganisms in the food or the release of toxins (Zarei et al 2014; Anyanwu et al; 2016).

Bacteria readily colonize the hands of food vendors, the counters from where the food is served, table surfaces on which the consumers take their meals and the utensils (Sinclair, et al 2011; FSIC: Food Safety Information Council 2016). Crowding, wetness of work surfaces and improper cleaning of kitchen equipment such as chopping boards, plates, knives, pots, bowls, mixers, refrigerators and other complex appliances like food processors, blenders and eggbeaters serve as good reservoir for microbes. Dish towels, hand towels, scrubbing sponges, garbage bins, sink drains and P-trap (the J-shaped pipe under the sink) are also not left out. The P-trap retains water over time and possibly seeps back up through the sink which may also enhance the spread of pathogens (Dru Sahai et al 2015). Poor personal hygiene practices amongst some food vendors further accelerate the rate of contamination. It is also observed that most of the cafeteria run a "pay as you eat system" where the students pay for their meals at the point of serving. Exchange of money between the "buyers" and the "sellers" with unprotected hands and minimal sanitary precautions are other predisposing factors (Anyanwu et al; 2016; Rakhshkhorshid et al 2016).

Microorganisms associated with food spoilage and cross contamination include Staphylococcus aureus, Bacillus sp., Salmonella, Listeria monocytogenes, Clostridium botulinum, mould, yeast and fungi (Anyanwu et al, 2016). These microorganisms have the ability to attach to surfaces and with high cell density form biofilms (Soltan Dallal, et al 2010). Epidemiological data on the incidence of foodborne diseases show that recurrent episodes of food borne diseases with symptoms ranging from diarrhoea, abdominal cramps 


\section{Macrothink}

and vomiting are a major cause of morbidity in the populace (Nweze, 2010).

The aim of this study is to determine the rate of bacterial contamination of crockery, cutleries and hands of food sellers in a University cafeteria as a step to ensure food safety and students well being

\subsection{Materials and Methods}

\subsubsection{Sample Collection}

Hand, crockery and cutlery swabs were collected from a university cafeteria in Ugbawka, Enugu state. The study area was chosen because the school's cafeteria is a commercial catering centre for both students and lecturers in the school. Samples were collected over a one month period. All swabs were collected weekly; the hands of the vendors were swabbed while cooking and serving.

\subsubsection{Serial Dilution and Enumeration of Bacteria}

Serial dilution was done for each sample to obtain 10 dilutions $\left(10^{-1}\right.$ to $\left.10^{-10}\right)$ by diluting 1 in $9 \mathrm{mls}$ of sterile peptone water, first from stock culture, then from subsequent dilutions. $0.1 \mathrm{ml}$ each of $10^{-5}$ and $10^{-6}$ dilution was then inoculated using spread plate technique for total aerobic plate count (TAPC) on Nutrient agar. Plates showing between 30 and 300 colonies were counted. Colony counts were expressed as colony forming units per $\mathrm{ml}(\mathrm{cfu} / \mathrm{ml})$ of sample. All counts were done in triplicate and average values were reported.

\subsubsection{Biochemical Tests}

The following tests were carried out on the isolates; catalase, coagulase, indole, oxidase, motility and Gram stain.

\subsubsection{Antibiotic Sensitivity Test}

Antibiotic sensitivity of the isolates was determined using previously established procedure by Cheesebrough (2006). Briefly, the isolates were cultured in nutrient broth at $37^{\circ} \mathrm{C}$ for $24 \mathrm{hr}$. Two loopful of the suspension of each isolate were inoculated into $20 \mathrm{ml}$ of sterile molten agar in $10 \mathrm{~cm}$ diameter Petri dishes and mixed. The plates were allowed to set and the antibiotic sensitivity discs were aseptically placed on their surfaces. The plates were incubated at $37^{\circ} \mathrm{C}$ for $24 \mathrm{hr}$ and the resultant inhibition zone diameters (IZDs) were measured and recorded 


\subsection{Results}

Table 1. Frequency of Samples Collected

\begin{tabular}{|c|c|c|}
\hline $\mathbf{S} / \mathbf{N}$ & Sample Type & Frequency of Sample Swabs \\
\hline 1 & $\mathrm{~A}$ & 10 \\
\hline 2 & B & 45 \\
\hline 3 & $\mathrm{C}$ & 20 \\
\hline 4 & $\mathrm{D}$ & 50 \\
\hline 5 & $\mathrm{E}$ & 9 \\
\hline \multirow[t]{2}{*}{6} & $\mathrm{~F}$ & 14 \\
\hline & \multicolumn{2}{|c|}{148} \\
\hline
\end{tabular}

\section{KEY}

A -Hand swab, B- Plates, C- Knives, D-Spoons, E- Pots, F- Tables

Table 2. Morphological Features of the Isolates on Different Media

\begin{tabular}{lllll}
\hline ISOLATES & NUTRIENT AGAR & $\begin{array}{l}\text { SALMONELLA } \\
\text { SHIGELLA AGAR }\end{array}$ & $\begin{array}{l}\text { EOSINE } \\
\text { BLUE }\end{array}$ & METHYLENE \\
\hline $\begin{array}{l}\text { Staphylococcus } \\
\text { aureus }\end{array}$ & golden colour & nil & nil & \\
Salmonella spp & Thin and even growth & Circular, flat & nil & \\
$\begin{array}{l}\text { Shigella spp } \\
\text { Klebsiella spp }\end{array}$ & Thin and even growth & Circular and milky & nil & \\
Escherichia coli & Slimy with raised growth & nil & Red & \\
\hline
\end{tabular}

Table 3. Biochemical Characteristics of the Isolates and the Possible Organisms

\begin{tabular}{l|l|l|l|l|l|l}
\hline ISOLATES & GS & CAT & COA & IND & OX & $\begin{array}{l}\text { POSSIBLE ISOLATES/ } \\
\text { FREQUENCY }\end{array}$ \\
\hline 1 & & & & & & Staphylococcus aureus $(25)$ \\
2 & + & - & + & - & - & Salmonella spp $(5)$ \\
3 & - & + & - & - & + & Shigella spp $(10)$ \\
4 & - & - & - & - & - & Klebsiella spp $(10)$ \\
5 & - & - & - & - & - & Escherichia coli $(15)$ \\
\hline
\end{tabular}

KEY:

GS- Gram staining, CAT- Catalase test, COA- Coagulase test, IND- Indole tset OX- oxidase test, (+) - positive, (- ) -negative

Table 4. Total Bacterial Count (Cfu/Ml) Dilution Factor $10^{-2}$

\begin{tabular}{l|c|l}
\hline S/N & Isolates & Average Bacteria Count \\
\hline 1 & Staphylococcus aureus & $8.4 \times 10^{\circ}$ \\
2 & Salmonella spp & $4.0 \times 10^{\circ}$ \\
3 & Shigella spp & $4.8 \times 10^{\circ}$ \\
4 & Klebsiella spp & $5.6 \times 10^{\circ}$ \\
5 & Escherichia coli & $5.2 \times 10^{\circ}$ \\
\hline
\end{tabular}




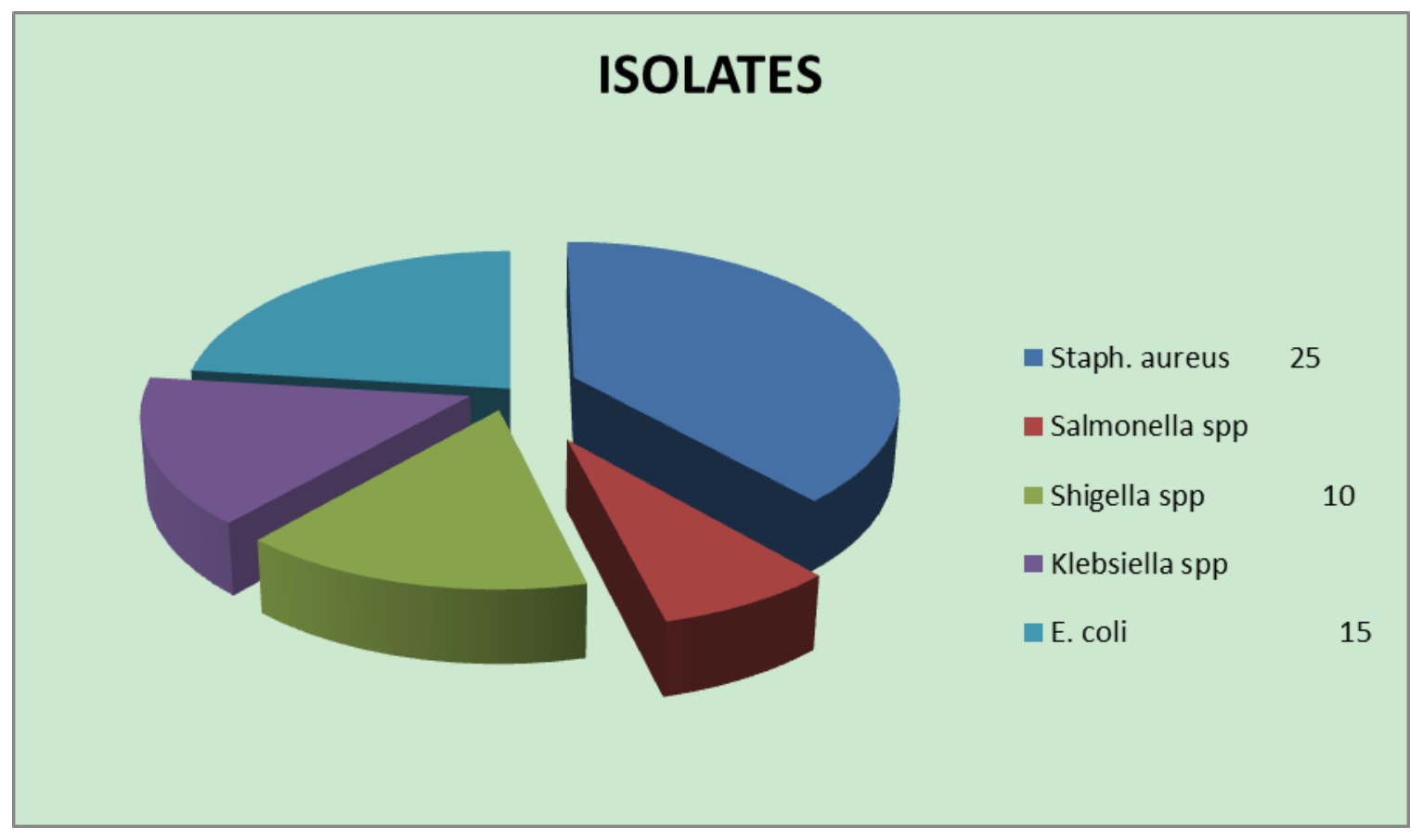

Figure 1. Distribution of Isolates from Sample Swabs

Table 5. Percentage Distribution of Isolates from Samples

\begin{tabular}{l|l|l|l|l|l}
\hline SAMPLE & $\begin{array}{l}\text { Staphylococcus } \\
\text { aureus }(\%)\end{array}$ & $\begin{array}{l}\text { Salmonella } \\
\text { spp }(\%)\end{array}$ & $\begin{array}{l}\text { Shigella } \\
(\%)\end{array}$ & $\begin{array}{l}\text { Klebsiella } \\
\text { spp }(\%)\end{array}$ & $\begin{array}{l}\text { Escherichia } \\
\text { coli }(\%)\end{array}$ \\
\hline A & $7(28 \%)$ & 0 & 0 & $5(50 \%)$ & $8(53.33 \%)$ \\
B & $5(20 \%)$ & 0 & $4(40 \%)$ & $3(30 \%)$ & 0 \\
C & $3(12 \%)$ & $5(100 \%)$ & $1(10 \%)$ & 0 & 0 \\
D & $5(20 \%)$ & 0 & $3(30 \%)$ & $2(20 \%)$ & $3(20 \%)$ \\
E & $2(8 \%)$ & 0 & $2(20 \%)$ & 0 & 0 \\
F & $3(12 \%)$ & 0 & 0 & 0 & $4(26.67 \%)$ \\
TOTAL & $\mathbf{2 5 ( 3 8 . 4 6 \% )}$ & $\mathbf{5 ( 7 . 7 0 \% )}$ & $\mathbf{1 0}(\mathbf{1 5 . 3 8 \%})$ & $\mathbf{1 0}(\mathbf{1 5 . 3 8 \%})$ & $\mathbf{1 5}(\mathbf{2 3 . 0 8 \%})$ \\
\hline
\end{tabular}

\section{KEY}

A -Hand swab, B- Plates, C- Knives, D-Spoons, E- Pots, F- Tables 


\section{Ml Macrothink}

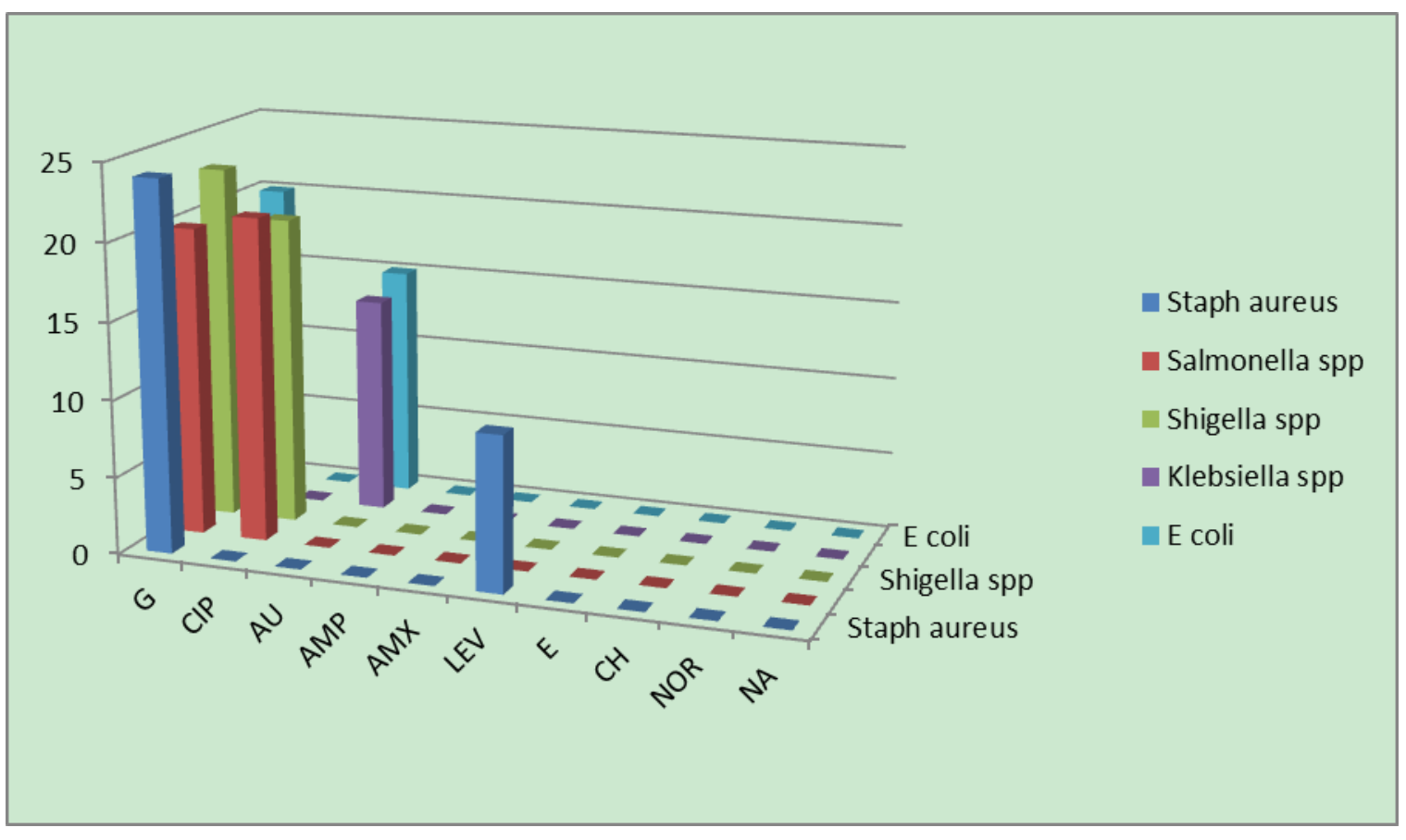

Figure 2. Susceptibility Pattern of the Isolates to Conventional Antibiotics

\section{KEY}

G- gentamicin, CIP-ciprofloxacin, AU- augmentin, AMP-ampicillin, AMX- amoxicillin,

LEV- levofloxacin, E- erythromycin, CH- chlorampenicol, NOR- norfloxacin,

NA- nalidixic acid

The different biochemical test was used in the identification of all the isolates. The Gram stain reaction confirmed Staphylococcus aureus as the only Gram positive isolate in the study while the other isolates Salmonella spp., Shigella spp., Klebsiella spp.and Escherichia coli are Gram negative. The results of the sensitivity testing shows that most of the isolates were not susceptibility to most of the antibiotics tested. The isolates however had varying sensitivity levels to gentamicin, ciprofloxacin, ampicillin and levofloxacin.

\subsection{Discussion}

The human hand is a major source of contamination because it may serve as a reservoir for microorganisms. Most food vendors handle vegetables and other food items with bare hands; which may encourage the transfer of pathogens in foods especially with those prepared and served uncooked like vegetable salad (Anyanwu et al 2016). In this study, the highest microbial isolates were obtained from hand swabs. Other organisms isolated are similar to those identified from other studies (Zarei, et al 2014; Rakhshkhorshid, et al., 2016). Some of these isolates identified could cause health hazard if ingested in food and this puts students and other consumers at risk of infection. This also confirms similar sources of food borne outbreaks which were reported in other university cafeteria (Shojaei et al 2006; Michael et al., 2011; Rakhshkhorshid, 2016). 
A common practice in the cafeteria is that the cooks dried their hands with their aprons; these garments could also serve as a source of further contamination. The bacterial counts of this study were $2.6 \times 10^{7} \mathrm{cfu} / \mathrm{ml}$ for hand swab, $8.0 \times 10^{5} \mathrm{cfu} / \mathrm{ml}$ for plates, $1.08 \times 10^{6} \mathrm{cfu} / \mathrm{ml}$ for knives, $9.6 \times 10^{5} \mathrm{cfu} / \mathrm{ml}$ for pots, $9.2 \times 10^{5} \mathrm{cfu} / \mathrm{ml}$ for spoons and $1.62 \times 10^{6} \mathrm{cfu} / \mathrm{ml}$ for tables. These high bacterial densities suggest contamination from crockery and cutleries leading to high morbidity in such environments. These findings are similar to the result of Moyo and Baudi, 2004.

The presence of Staphylococcus aureus poses a threat to human health because it can lead to food poisoning or food intoxication when the food is not properly preserved or refrigerated which is more severe and persist when the organism is destroyed (www.foodsafety.gov.2016). Isolation of Staphylococcus aureus is an indication of poor sanitary conditions and use of dirty towels (Ibekwe et al., 2008). The organism is pathogenic and survives for longer period in water than the coliforms. Salmonella in the cafeteria is worrisome as it is a major cause of food borne illness (salmonellosis) and is responsible for majority of cases of illness yearly (www.foodsafety.gov.2016).

Although E. coli is a normal flora of the gut and is not harmful, its presence suggests faecal contamination of the food and also and is an indication that other pathogenic microbes are present namely Salmonella and Shigella which were also identified in this study. E. coli can be a source of opportunistic infection and is associated with intestinal diseases in humans with symptoms ranging from stomach cramps, fever and diarrhoea depending on the virotypes.

Spoons and plates also had high levels of contamination which may be due to methods of washing; insufficient and inappropriate washing methods such bulk washing, lack of disinfection and use of undrinkable water may also be a contributing factor (Gholammostafaei et al 2014).

The low values recorded from the serving tables may be due to the thorough disinfection done before meals are served to the students and the use of disposable napkins for cleaning in between servings.

\subsection{Conclusion and Recommendation}

The presence of these isolates suggests poor personal hygiene and general neglect of food safety procedures which can pose a health hazard to consumers. Proper sanitary practices during food processing can reduce microbial contamination to safe levels. Enlightenment on food safety and cafeteria hygiene should be put in place with periodic supervisions to ensure adherence to the guidelines. Personal and environment hygiene should also be emphasized. Hand washing techniques and the use of alcohol base hand sanitizers should also be adopted.

\section{References}

Anyanwu, N. C. J., John, W. C., \& Idoko, M. O. (2016) Bacteriological Examination of the Cafeteria Equipments in Karu L.G.A Cafeterias, Nasarawa State, Nigeria. Journal of Applied Life Sci Int'l., 5(2), 1-8. https://doi.org/10.9734/JALSI/2016/26243 
Cheesbrough, M. (2006). District Laboratory Practice in Tropical Countries. (2 ${ }^{\mathrm{ND}}$ ed). Cambridge University Press. 62, 112-115. https://doi.org/10.1017/CBO9780511543470

Dru, S., Emily, P., \& Ye, L. (2015). Microbiological Assessment of Utensils Cleaned by Domestic Dishwashers in Ontario Small Establishments. Food Protection Trends, 35(3), $185-195$.

Edema, M. O., Osho, A. T., \& Diala, C. I. (2008). Evaluation of microbial hazards associated with the processing of suya (a grilled meat product). Science Research Essay; 3 , 621-625.

Food Safety Information Council Cross-Contamination (2016). http://www.foodsafety.asn.au/resources/kitchen-food-safety

Gholammostafaei, F., Alebouyeh, M., \& Jabari, F. (2014). Prevalence of Antibiotic Resistant Bacteria Isolated from Foodstuff in Kitchen of a Hospital in Tehran. Journ of Ilam University of Med. Sci., 22(2), 1-9.

Ibekwe, A. C., Okono, I. O., Onukwe, A. U., Dunbraye, E., \& Onoja, B. A. (2008). Baseline Salmonella agglutin titres in apparently healthy fresh meat in Akwa, south Eastern Nigeria. Sci Res. Essay., 3(9), 225-230.

Majlesi, N. M., Jabbari, F., Alebouyeh, M., Torabi, P., Balvayeh, M., \& Zali, M. R. (2014). Risk assessment of cooking utensils role of the bacterial contamination in the hospital kitchen. Iranian South Med. Journal, 17(3), 336-344.

Michael, P., \& Roger, D. (2011). Environmental Microbiology ( $3^{\text {rd }}$ Edn). London. Crawford Publisher. P.147

Moyo, D. Z., \& Baudi, I. (2004). A bacteriological Assessment of the cleaning and disinfectant efficacy at the Midland university canteen, Zimbabwe. Journ. of Biological. Sci., 7(11), 1996-2001.

Nweze, E. A. (2010). Aetology of diarrhoea and virulence properties of diarrhoeagenic E.coli among patients and healthy subjects in South East Nigeria. Journ. of Health Population. $28(3), 243-252$.

Okonke, I. O., Adeboye, O. D., Ogun. A. A., \& Ogunjobi, A. O. (2009). Hazard Analysis Critical Control Point (HACCP) and microbiological quality of sea foods as affected by handlers hygiene in Ibadan and Lagos, Nigeria. African Jorn .Food Sci., 3, 35-50.

Oranusi, U. S., \& Braide, W. (2012). A study of microbial safety of ready-to-eat foods vended on highways: Onitsha-Owerri, south east Nigeria. Int'l Research Journ of Microbio, 3(2), 066-071.

Rakhshkhorshid, M., Rakhshkhorshid, A., \& Belarak, D. (2016). Survey of cooking utensils and dishes microbial contamination rate in the cafeteria of Zahedan University of medical sciences, 2015. Int'l Journ of Biomed and Healthcare Sci; 6(2), 187-193.

Shojaei H., J. Shooshtaripoor J., \& Amiri, M. (2006). Efficacy of simple hand washing in 


\section{Macrothink}

eduction of microbial hand contamination of Iranian food handlers. Food res. Int'l., 39, 525-529.

Sinclair, R. G., \& Gerba, C. P. (2011) Microbial contamination in kitchens and bathrooms of rural Cambodian village households. Journ of Mcbio; 52, 142-149. https://doi.org/10.1111/j.1472-765X.2010.02978.x

Soltan, D. M. M., Fazelifard, P., Tabatabaei, B. A., Rashidi, S., \& Zarrin, M. (2010). Determination the rate of microbial contamination of cream pastry from confectionaries in south of Tehran. Journ of Microb Biotech, 2(6), 7-12.

www.foodsafety.gov. Food poisoning: Causes, bacteria and viruses, Staphylococcus; 2016. Available: https://www.foodsafety.org/poisoning(Accessed on 10th January, 2016)

Zarei, S., Ehrampoush, M. H., Mazloomi, S. M., Ghaneian, M. T., \& Hajimohammadi, B. D. (2014). A.Evaluation of microbial quality of sausage slicers at food retail food stores in Shiraz, Iran. Journal of Toloo-e-Behdasht., 13(3), 54-63.

\section{Copyright Disclaimer}

Copyright for this article is retained by the author(s), with first publication rights granted to the journal.

This is an open-access article distributed under the terms and conditions of the Creative Commons Attribution license (http://creativecommons.org/licenses/by/3.0/). 